\title{
Pormestarimalli kuntajohtamisen muotona
}

Pormestarimalliin liittyvät tavoitteet, odotukset ja uskomukset

TIIVISTELMÄ Pormestarimalliin kohdistuva kiinnostus on Suomessa kasvanut maltillisesti viime vuosina. Tässä artikkelissa on tarkasteltu niitä aiemmassa tutkimuksessa ja suomalaisessa julkisessa keskustelussa esiintyviä argumentteja, joilla pormestari- ja virkajohtajamalleja perustellaan ja vastustetaan. Artikkeli tuottaa uutta tietoa pormestarimalliin liitetyistä tavoitteista, odotuksista ja uskomuksista. Tutkimuksen empiirinen aineisto koottiin pormestarimallia koskevasta internetistä kerätystä media-aineistosta. Aineisto analysoitiin teorialähtöisesti rakennetun analyysikehikon ohjaamana keskittyen johtamisen ammattimaisuuteen, poliittisen johtamisen vahvistamiseen, demokratian edistämiseen sekä johtamisen selkeyteen liittyviin argumentteihin. Analyysin tuloksena tunnistettiin neljä väittämäparia, jotka tiivistävät pormestarimalliin liittyviä uskomuksia, odotuksia ja tavoitteita. 1) Pormestarimallin uskotaan vahvistavan demokratiaa, mutta keskittävän valtaa. 2) Poliittisen johtamisen uskotaan vahvistuvan, mutta johtamisen epäammattimaistuvan. 3) Pormestarimallin avulla uskotaan voitavan murtaa status quo, ja samalla johtamisen aikajänteen arvellaan lyhenevän. 4) Pormestarimallin uskotaan parantavan kunnan ja kuntalaisten välistä suhdetta ja selkeyttävän poliittisen ja virkajohdon välistä suhdetta. Kokonaisuutena tarkastellen pormestarimalliin liitettävät uskomukset, odotukset ja tavoitteet ovat varsin epämääräisiä ja abstrakteja. Pormestarimallilla uskotaan päästävän perustavanlaatuiseen ja kokonaisvaltaiseen kuntajohtamisen muutokseen, jossa muutoksen kohteena ei ole pelkästään kunnan johtohahmo, vaan laajemmin kuntajohtamisen rytmi, suunta ja perusta. 


\section{JOHDANTO: PORMESTARIMALLI TUTKIMUSKOHTEENA}

Suomalaiset kunnat ovat parin viime vuosikymmenen aikana olleet jatkuvan, laajamittaisen muutoksen kourissa. Tässä muutoksessa on tiivistetysti kyse kuntien toimintaympäristön muutoksesta, globaalien haasteiden ratkaisemisen tulemisesta kuntajohtamisen keskiöön, hallinnon reformeista, kuntien tehtävämäärän kasvusta sekä kuntien eriytymiskehityksestä. Suomalaisten kuntien näkökulmasta vuosituhannen vaihteessa alkanutta ajanjaksoa voi luonnehtia suuren murroksen ajaksi.

Kuntien toimintaympäristön muuttuessa muutostarpeet kohdistuvat myös kuntajohtamiseen. Yksi keskeinen osa kuntajohtamista on se, minkälaisen johtamismallin varaan kuntajohtaminen rakentuu. Kunnan johtamismallilla tarkoitamme tässä artikkelissa sitä, valitaanko kunnan ylimmäksi johtajaksi kunnanjohtaja (virkajohtaja) vai pormestari (puoluepoliittisin perustein valittu luottamushenkilöjohtaja). Suomen suurimmissa kaupungeissa kyse on ylimmän johtajan lisäksi myös apulaisjohtajista, jotka voivat olla joko virkajohtaja- tai pormestarinimikkeellä (apulaiskaupunginjohtajia tai apulaispormestareita).

Suomessa on perinteisesti ollut käytössä johtamismalli, jossa kunnan johtohenkilönä on kunnanjohtaja, joka toimii kunnan ylimpänä viranhaltijana. Virkajohtajamallin sijaan Euroopassa valtavirtaa on pormestarimalli, mutta Suomessa pormestarimalli on verrattain uusi ja vielä harvinainen johtamismalli, vaikkakin myös meillä on viime vuosina käyty siitä runsaasti julkista keskustelua. Osa kunnista on jo päättänyt siirtyä pormestarimalliin. Tämä on ollut Suomessa mahdollista vuodesta 2006 alkaen, kun kuntalakia muutettiin siten, että kunta voi valita ykkösjohtajakseen viranhaltijana toimivan kunnanjohtajan sijasta myös luottamushenkilönä toimivan pormestarin. Pormestarimallista keskusteltiin jo vuoden 1995 kuntalain uudistuksen yhteydessä, mutta pormestarin nimikkeen tuomista suomalaiseen kunnallishallintoon ei kuitenkaan ehdotettu (HE 192/1994, 31).

Vuoteen 2020 mennessä pormestarimalliin siirtyneitä kuntia on kuusi: Tampere (2007), Pirkkala (2009), Helsinki (2017), Tuusula (2017), Kärkölä (2018) ja Puolanka (2018). Lisäksi Lahti ja Turku ovat päättäneet pormestarimalliin siirtymisestä. Lahti kuitenkin perui päätöksen myöhemmin, joten pormestarikuntien joukkoon liittyy vuoden 2021 kuntavaalien myötä Turku. Tällä vuosituhannella ainakin Espoossa, Heinolassa, Hämeenlinnassa, Imatralla, Jämsässä, Kokkolassa, Kotkassa, Nokialla, Oulussa, Porissa, Rovaniemellä, Salossa, Seinäjoella, Vantaalla ja Vihdissä on pohdittu pormestarimalliin siirtymistä. Pormestarimalli ei ole toistaiseksi saanut kovinkaan laajaa kannatusta kuntapäättäjiltä ja kuntalaisilta, mutta kiinnostus sitä kohtaan on ollut maltillisesti kasvavaa. (Haveri 2020; Uutissuomalainen 2020.)

Virkajohtaja- ja pormestarimallin välisessä valinnassa on kyse paitsi kunnan johtohenkilön asemasta ja roolista, myös laajemmasta johtamisjärjestelmää koskevasta muutoksesta, jolla on monenlaisia vaikutuksia kunnan poliittiseen ja viranhaltijaorganisaatioon, sekä kunnan toimintatapoihin ja -kulttuuriin. Virkajohtaja- ja pormestarimallien vaikutuksista kaupungin hallintaan ja sen tehokkuuteen, vaikuttavuuteen ja demokraattisuuteen on tehty jonkin verran tutkimusta Yhdysvalloissa (katsaus aiheeseen ks. Carr 2015), mutta Euroopassa vähän. Eurooppalaisen tutkimuksen vähäisyyttä selittänee se, että virkajohtajamalli on selvästi marginaalinen Euroopassa, ja eurooppalaisessa tutkimuksessa enemmän kiinnostusta ovat siten herättäneet pormestarimallin eri variaatiot. 
Pormestarimalliin liittyvä suomalainen tutkimus on toistaiseksi ollut vielä varsin vähäistä. Suomalainen pormestaritutkimus on liittynyt erityisesti Tampereen toimintamallin muutokseen ja sen arviointiin (ks. esim. Hakari 2009; Hakari ym. 2013; Stenvall ja Airaksinen 2009). Tuoreimpana esimerkkinä aihepiirin tutkimuksesta on Helsingin johtamisjärjestelmän uudistukseen liittyvä arviointitutkimus (Haveri ym. 2021; Jäntti ym. 2021). Pormestarimalliin liittyviä opinnäytetöitä on Suomessa tehty jonkin verran. Niissä on tarkasteltu pormestarin funktiota (Katainen 2005), pormestarin tilivelvollisuutta (Korkeila 2017; Marttinen 2019), poliittisen johtamisen ammattimaistumista (Marin 2017), pormestarimallin vaikutusta viranhaltija- ja luottamushenkilöorganisaation väliseen valtasuhteeseen (Liljeroos 2018) ja poliittista johtajuutta pormestarikunnissa (Moilanen 2020).

Aihepiiristä julkaistut suomalaiset tutkimukset eivät juurikaan käsittele pormestarimalliin liittyviä odotuksia ja uskomuksia. Tutkimuksemme viitekehys koostuu siksi pääasiassa muiden maiden pormestarimalleja koskevasta kansainvälisestä tutkimuksesta. Pormestarimalliin kohdistuvan kiinnostuksen kasvaessa aihepiiriin liittyvälle tutkimukselle on aiempaa enemmän tarvetta. Lisäksi kuntajohtamisen käytäntöjen moninaistuessa myös johtamismallien osalta avautuu uusia kuntajohtamisen tutkimukseen liittyviä kysymyksiä ja mahdollisuuksia. Tutkimuksen vähäisyys onkin suomalaisesta näkökulmasta hieman yllättävää, kun otetaan huomioon johtamismallien saama huomio julkisessa keskustelussa, ja se että mallit ovat monissa kunnissa selkeässä kilpailuasetelmassa keskenään. Mallien kannattajat pyrkivät tuomaan esille oman suosikkinsa paremmuutta korostamalla sen todellisia tai oletettuja etuja ja nostamalla esiin toisen mallin haittoja. Tutkittu tieto helpottaisi mallien arvioimista ja kohentaisi malleista käytävän julkisen keskustelun laatua.

Aiemman tutkimuksen perusteella tiedetään, että kunnan johtamismallin muutosta harkitaan monenlaisista syistä (esim. Fenwick ja Elcock 2014; Goldsmith ja Larsen 2004; Jäntti ym. 2021; Svara ja Watson 2010; Wollmann 2014). Johtamismallin muutoksen noustessa agendalle keskustelussa ilmenee erilaisia odotuksia ja uskomuksia, joita eri johtamismalleihin liitetään. Tässä tutkimuksessa tarkastelemme olemassa olevan tutkimuksen sekä media-aineiston analyysin avulla niitä argumentteja, joilla johtamismalleja perustellaan ja vastustetaan.

Tämän artikkelin tarkoituksena on tuottaa uutta tietoa pormestarimalliin liitetyistä tavoitteista sekä siihen kohdistuvista odotuksista ja uskomuksista. Tutkimusotteemme on laadullinen, kuvaileva ja uutta ymmärrystä tuottava. Artikkelin teoreettinen kehys rakentuu erityisesti kansainvälisen kuntajohtamistutkimuksen varaan, ja sen tarkoituksena on tarjota viitekehys sen ymmärtämiseksi, minkälaisia piirteitä kuntajohtamisen erilaisiin johtamismalleihin liitetään. Aiemman tutkimuksen pohjalta teemme synteesin niistä kansainvälisessä tutkimuskirjallisuudessa esiintyvistä tekijöistä, joilla johtamismallin valintaa perustellaan. Tätä synteesiä hyödynnämme analyyttisena kehikkona tutkimuksen empiirisen aineiston analysoinnissa.

Tutkimuksen empiirisen aineiston olemme koonneet pormestarimallia koskevasta suomalaisesta tekstimuotoisesta media-aineistosta. Analysoimme aineistoa laadullisesti kansainvälisen tutkimuksen valossa. Tutkimuskysymyksinämme ovat, mitä pormestarimallilla tavoitellaan, mitä siltä odotetaan ja miten pormestarimallin valintaa perustellaan.

Vaikka tutkimuskohteenamme on pormestarimalli ja mahdollinen siirtyminen siihen, kuvaamme ensin yleisemmin pormestari- ja virkajohtamismalleihin liittyvää keskustelua tutkimuskirjallisuuteen nojautuen. Tämän jälkeen tarkastelemme kansainvälisen tutkimuksen 
perusteella kuntajohtamismalleihin liitettäviä vahvuuksia ja heikkouksia ja teemme synteesiin malleihin liitetyistä perusteluista. Tähän synteesiin pohjautuen muodostamme analyysikehikon, joka toimii puitteena pormestari-virkajohtajakeskustelua koskevan media-aineistomme laadulliselle sisällönanalyysille. Tämän jälkeen esittelemme tutkimusaineiston ja analyysimenetelmän sekä -prosessin ja kuvaamme media-aineiston analyysin tulokset. Lopuksi kuvaamme pormestarimalliin liittyviä tavoitteita ja odotuksia, mutta myös pelkoja ja uhkia, ja pohdimme millaisia uskomuksia ja tulkintoja johtamismallin vaihtamiskeskustelussa nousee esille.

\section{PORMESTARI JA VIRKAJOHTAJA KUNNAN JOHTOHAHMOINA}

Kuntajohtamisen, kuten laajemminkin julkisen johtamisen, keskeinen jännite palautuu kysymykseen hallinnon ja politiikan välisestä suhteesta sekä toimijoiden oikeasta työnjaosta ja rooleista. Pormestari edustaa lähtökohtaisesti poliittista ja virkajohtaja hallinnollista johtamista, joskaan rajanveto ei ole yksiselitteisen selvää.

Pormestari-virkajohtaja-dikotomian tarkastelulla on myös rajoituksensa. Kuntajohtamisessa on aina kysymys johtamisjärjestelmän kokonaisuudesta, johon keulahahmon eli pormestarin tai virkajohtajan ohella kuuluu monia instituutioita, jotka vaihtelevat maittain tai jopa kunnittain. Esimerkiksi suomalaisessa kuntajohtamista koskevassa tutkimuksessa kunnan laajan tehtäväkentän ja eri tahojen välisten valtasuhteiden on todettu vaikuttavan paljon kuntajohtajien toimenkuvaan (Leinonen 2012). Paikallisesti omaleimaiset kulttuurit ja kuntajohtamisen kannalta olennaisimmiksi tunnistetut rajapinnat ja vuorovaikutustahot vaikuttavat kuntajohtamiseen ja johtamisjärjestelmiin. Myös poliittiset päätöksentekokulttuurit vaihtelevat suuresti. Kunnat, jotka esimerkiksi talouden tai väestön tunnuslukuja tarkastelemalla ovat näennäisesti samanlaisia, voivat erota huomattavastikin johtamisjärjestelmiensä ja keulahahmojensa roolien (virkajohtaja ja esimerkiksi hallituksen puheenjohtaja) osalta myös virkajohtajamallin sisällä. (Haveri ym. 2015.) Suomalaisessa kuntajohtamisessa korostuu jo kuntalain (410/2015) luomista lähtökohdista kollektiivien ja erityisesti kunnanhallituksen rooli yksittäisten henkilöiden roolin sijaan.

Pormestari-virkajohtaja-dikotomia ei muutoinkaan riitä täydellisesti kuvaamaan eri maiden johtamismallien variaatioita. Esimerkiksi Norjassa kuntien johtamismalli perustuu vahvan lakisääteisen virkajohtajan (kommunedirektør) ja vahvan luottamushenkilöjohtajan (ordfører) rinnakkaiseloon (ks. esim. Røiseland ja Vabo 2020). Toisaalta kaikki pormestarit tai virkajohtajatkaan eivät ole keskenään samanlaisia. Vertailtaessa kuntien johtamisjärjestelmiä kansainvälisesti huomio kiinnittyy erilaisten mallien laajaan kirjoon. Variaatio johtuu sekä paikallishallintojen historiasta ja kulttuurista että erilaisista hallintojärjestelmistä. Käytössä on lukuisia erilaisia pormestarimalleja eli pormestarien johtamia kuntia, ja toisaalta erilaisia virkajohtamiseen perustuvia virkajohtajaperusteisia malleja. Yleisesti Euroopassa pormestarien johtamat kunnat ovat selkeästi valtavirtaa, kun virkajohtajamalli on käytössä lähinnä vain Suomessa, Irlannissa ja Islannissa. Yhdysvalloissa puolestaan virkajohtajamalli on nykyään vallitsevampi suurimpia kaupunkeja lukuun ottamatta.

Euroopassa pormestarimallissa on kaksi päävaihtoehtoa: suoralla kansanvaalilla valittavan pormestarin malli sekä valtuuston valitseman pormestarin malli. Suomessa näistä malleista 
käytössä on vain valtuuston valitseman pormestarin malli; kuntalaki (410/2015) ei nykymuodossaan mahdollista suoralla vaalilla valittua pormestaria. Valtuuston valitsema pormestari on tyypillisempi sellaisissa maissa, joissa kunnilla on laaja tehtäväkenttä ja suuri vastuu palvelujen järjestämisestä. Esimerkiksi Pohjoismaissa pormestari on tyypillisesti valtuuston valitsema. Suoralla vaalilla valittava pormestari on Euroopassa yleisempi kuin valtuuston valitsema pormestari. Vuonna 2006 yli kaksi kolmasosaa eurooppalaisista pormestareista oli valittu suoralla vaalilla (Magnier 2006). Pormestari valitaan suoralla vaalilla esimerkiksi Saksassa, Ranskassa, Espanjassa ja Italiassa. Alankomaissa, Belgiassa ja Luxemburgissa taas valtion keskushallinto vahvistaa pormestarien nimitykset, ja pormestareilla on paikallisten tehtävien lisäksi myös valtiollisia tehtäviä. Yhdysvalloissa useimmissa virkajohtajakaupungeissakin on pormestari, jonka rooli johtajana on kuitenkin heikompi kuin pormestarimallin kaupungeissa tai peräti lähes kokonaan seremoniallinen (Svara 2003).

Viime vuosikymmenien kehitys Euroopassa on kulkenut suoralla vaalilla valittavan pormestarin suuntaan. Etenkin monissa Itä-Euroopan maissa, kuten Puolassa ja Romaniassa sekä entisen Itä-Saksan osavaltioissa, on otettu käyttöön malli, jossa pormestari valitaan suoralla kansanvaalilla. Suoran kansanvaalin suosio on lisääntynyt myös läntisen Saksan osavaltioissa, Britanniassa ja Norjassa. (Ks. esim. Larsen 2002.) Virkajohtajamalliin ei ole vastaavasti siirrytty juuri missään Euroopan maassa tällä vuosituhannella. Euroopan maissa keskustelua käydään lähinnä pormestarien valintatavasta ja muista pormestarien asemaan ja valtaan vaikuttavista tekijöistä kuten riippumattomuudesta ja tehtävistä sekä heidän suhteestaan kunnan hallintoelimiin.

Kansainvälisen kaupungin- ja kuntajohtajien yhdistyksen kyselyn mukaan vuonna 2011 Yhdysvaltain kunnista reilussa kolmanneksessa oli käytössä pormestarimalli loppujen ollessa virkajohtajien johtamia. Pormestarikunnista lähes kaikissa pormestari valitaan suoralla vaalilla. (ICMA 2011.) Yhdysvalloissa kehitys on ollut Eurooppaan verrattuna päinvastaista, sillä siirtymää on tapahtunut pormestarimallista virkajohtajamalliin erityisesti pienemmissä kaupungeissa. (Carr 2015, 673; Choi ym. 2013.) Yli sadan tuhannen asukkaan kaupungeissa muutosta on tapahtunut sekä virkajohtajamallista (council-manager) pormestarimalliin (mayor-council) että pormestarimallista virkajohtajamalliin. (Svara ja Watson 2010.)

\section{MINKÄLAISIA PIIRTEITÄ KUNNAN JOHTAMISMALLEIHIN LIITETÄÄN?}

Aiemman tutkimuksen perusteella tiedetään, että kunnan johtamismallin muutokseen liittyvät syyt voivat johtua toimintaympäristön muutoksesta, luottamushenkilötyön vaativuuden kasvusta ja paikallisen poliittisen johtamisen ammattimaistumisesta, tyytymättömyydestä johtamiseen ja vallanjakoon sekä käytännöllisistä syistä, kuten kunnanjohtajan eläköitymisestä tai siirtymisestä toisiin tehtäviin (esim. Fenwick ja Elcock; Goldsmith ja Larsen 2004; Jäntti ym. 2021; Svara ja Watson 2010; 2014; Wollmann 2014). Tässä artikkelissa keskitymme tarkastelemaan sitä, minkälaisilla perusteilla eri mallien puolesta - tai niitä vastaan - argumentoidaan asian noustua agendalle.

Johtamismalleihin liitetyt perustelut voivat olla luonteeltaan tutkimukseen perustuvia, ideologisia tai puhtaita uskomuksia. Perusteluissa eri mallien kannattajat pyrkivät tuomaan esille 
oman suosikkinsa paremmuutta korostamalla sen todellisia tai oletettuja etuja ja nostamalla esiin toisen mallin haittoja. Tutkimustulokset eri mallien vaikutuksista ovat kuitenkin harvoin yksiselitteisiä. Esimerkiksi Alex Marsh (2012) toteaa, että suoralla vaalilla valitun pormestarin tuomista eduista ei ole olemassa vahvaa tutkimuksellista näyttöä.

Minkälaisia tavoitteita pormestari- ja virkajohtajamalleihin liittyy, ja miten johtamismallin muutostilanteissa on perusteltu mallien soveltuvuutta kunnan johtamiseen? Olemme jaotelleet johtamismallin muutokseen liittyvät tavoitteet ja perustelut aiemman tutkimuksen perusteella neljään ryhmään, jotka koskevat: 1 . johtamisen ammattimaisuutta, 2. poliittisen johtamisen vahvistamista, 3. demokratian edistämistä sekä 4. johtamisen selkeyttä.

\section{Johtamisen ammattimaisuus}

Kun pohditaan johtamismallin muuttamista pormestarimallista virkajohtajamalliin tai päinvastoin, yhtenä tarkastelunäkökulmana on johtamisen ammattimaisuus. Johtamisen ammattimaisuuteen liittyvissä perusteluissa korostetaan esimerkiksi johtamisen tehokkuutta, objektiivisuutta, eettisyyttä ja jatkuvuutta.

Yhdysvalloissa tarvetta siirtyä pormestarimallista virkajohtajamalliin on perusteltu nimenomaan sillä, että virkajohtajamallin kautta kuntajohtamiseen voidaan paremmin tuoda yritysmäistä, tehokkuutta korostavaa johtajuutta ja vähentää johtamisen politisoitumista (Choi ym. 2013). Virkajohtajamallin paremmuutta perustellaan johtajan tuomalla asiantuntemuksella ja pitkäjänteisyydellä. Virkajohtajan katsotaan myös tuovan päivittäiseen johtamiseen ammattimaisuutta, tehokuutta ja vaikuttavuutta sekä antavan valtuustolle objektiivista tietoa päätöksenteon tueksi pormestarimallia paremmin. Taustalla on myös ajatus virnahaltijoiden ja poliittisten johtajien kesken jaetun johtajuuden paremmuudesta suhteessa pormestarimalliin liittyvään vallan keskittämiseen. (Svara ja Watson 2010.)

Toisaalta samoja argumentteja johtamisen tehostumisesta voidaan käyttää myös pormestarimallin puolesta niin kuin on tehty erimerkiksi Isossa-Britanniassa. Siellä keskusta-oikeistolaisessa ajattelussa pormestarimallia on perusteltu juuri tehokkuusargumenteilla: pormestarimallin on uskottu tuovan mahdollisuuksia virtaviivaistaa ja tehostaa johtamista (Fenwick ja Elcock 2014; 2016).

\section{Poliittisen johtamisen vahvistaminen}

Johtamisen ja vallanjaon toimivuus on yksi keskeinen syy, jonka vuoksi kunnissa päädytään vaihtamaan johtamismallia. Usein näissä tilanteissa taustalla on halu ja tarve vahvistaa poliittista johtamista. Tähän tavoitteeseen uskotaan usein olevan mahdollista päästä pormestarimallin avulla.

Kuntien käsittelemien ongelmien monimutkaistuessa poliitikoilta vaaditaan yhä enemmän aikaa ja osaamista. Politiikka ja poliittinen johtaminen ammattimaistuvat, mikä lisää tarvetta parantaa paikallispoliitikkojen toimintaedellytyksiä, työhön käytettävää aikaa ja siitä saatavaa korvausta sekä tarkastella uudelleen luottamushenkilöiden roolia. Paikallispolitiikkaa on aiemmin pidetty 
vapaaehtoistyön kaltaisena amatööriluottamushenkilöiden omistautumisena paikalliseen toimintaan, mutta sittemmin politiikka on myös paikallistasolla muuttumassa enemmän ammattimaiseksi tai jopa kokopäiväiseksi palkkatyöksi erityisesti suurissa kaupungeissa. (Guérin ja Kerrouche 2008.) Kehitys on ollut samankaltaista myös Suomessa. Luottamushenkilöiden ajankäyttöä selvittäneessä tutkimuksessa ilmeni, että suurissa kunnissa puheenjohtajien käyttämä aika luottamustehtävän hoitamiseen vastaa noin puolipäiväistä työtä. Lisäksi kokopäivä- ja osa-aikatoimisten luottamushenkilöiden määrä on kasvussa. (Sandberg 2016.) Tämänkaltainen kehitys kuvastaa politiikan ammattimaistumista ja voi osaltaan johtaa pormestarimallin kannatuksen kasvuun.

Yhdysvalloissa pormestarimallin etuna pidetään sen mahdollistamaa vahvaa johtajuutta ja sitä kannatetaan silloin, kun halutaan vahvistaa poliittista johtajuutta. Suuri osa pormestarimallin puolesta argumentoinnista tapahtuu moittimalla virkajohtajamallia. Kriitikoiden mukaan malli ei mahdollista valtuuston strategista toimintaa, jakaa valtaa liiaksi ja hajottaa näin toimijoiden vastuullisuutta sekä kerryttää virkajohtajalle tämän roolin vastaisesti liikaa valtaa. (Svara ja Watson 2010.) Virkajohtajamallin paremmuutta puolestaan on perusteltu sillä, että pormestarimallin epäillään olevan herkkä korruptiolle ja suosimiselle sekä edistävän tuhlaamista ja tehottomuutta (Feiock ym. 2003; Svara ja Watson 2010).

Englannissa pormestarimalliin siirtymisen puolesta on argumentoitu kuntajohtamiseen liittyvillä ongelmilla läpi puoluekentän. 1800-luvulle juurensa ulottavan perinteisen johtamismallin ei ole enää nähty kykenevän vastaamaan nykyajan tarpeisiin. Tavoitteena on ollut uudistaa paikallishallintoa pormestarimallin avulla vahvistamalla paikallista johtajuutta, virtaviivaistamalla päätöksentekoa ja parantamalla vastuusuhteiden läpinäkyvyyttä (Hambleton ja Sweeting 2004).

Pormestarin aseman on uskottu mahdollistavan strategisten johtamishaasteiden osoittamisen ja vaikeiden päätösten tekemisen. Lisäksi suoralla vaalilla valittava pormestari saa vaaleissa vahvan legitimiteetin johtaa kuntaa, mikä lisää hänen vaikutusvaltaansa ja siten vahvistaa poliittista johtamista. (Hambleton 2013.) Vaaleilla valittavaa pormestaria on perusteltu myös sillä, että mallin katsotaan luovan mahdollisuuksia taloudellisten, sosiaalisten ja ympäristöön liittyvien tavoitteiden saavuttamiseksi (DCLG 2011). Pormestarista on kaavailtu vahvasti ulospäin suuntautuvaa, vaikutusvaltaista poliittista johtajaa ja kunnan ja kuntalaisten näkyvää edunvalvojaa, joka puhuu kuntansa puolesta ja jota myös kuunnellaan (Sweeting 2003).

Suomalaisista kunnista ensimmäisenä pormestarimalliin siirtyi Tampere, jossa haluttiin yhdistää poliittinen johtajuus kiinteämmin operatiiviseen johtamiseen. Pormestarimalliin siirtymisellä on haluttu Suomessa myös vahvistaa valtuuston ja hallituksen asemaa ja poliittista valtaa, kasvottaa ja parantaa demokraattista päätöksentekoa sekä selkeyttää ja vahvistaa poliittista ohjausta. (Hakari ym. 2013; Jäntti ym. 2021.)

\section{Demokratian edistäminen}

Pormestarimallin puolestapuhujat perustelevat asiaa usein demokratian näkökulmasta. Esimerkiksi Englannissa vasemmistolaisessa ajattelussa korostuvat odotukset pormestarimallin myötävaikutuksesta paikallisen demokratian edistämiseen ja kansalaisyhteiskunnan vahvistumiseen. (Fenwick ja Elcock 2014; 2016.) Demokratianäkökulmaa on käytetty kuitenkin myös 
pormestarimallia vastaan. Pormestarimallia on moitittu yksilökeskeisyydestä, sillä toiminnan on katsottu olevan pormestarimallissa liian riippuvaista yhdestä henkilöstä. Keskitetyn johtamisen on katsottu heikentävän vähemmistöjen mahdollisuutta saada äänensä kuuluviin, mikä voi lisätä jännitteisyyttä vallassa ja oppositiossa olevien ryhmittymien välillä. (Feiock ym 2003; Svara ja Watson 2010.)

Englantilaisessa keskustelussa pormestarimallin tuoman vahvan johtajuuden on uskottu hyödyttävän asukkaita. Mallin on katsottu lisäävän kuntalaisten osallistumista ja kiinnostusta paikallispolitiikkaan sekä parantavan demokratiaa (DCLG 2011; Lodge 2012.) Myös Saksassa ja Italiassa on korostettu pormestarimallin demokratia-aspektia. Suoralla vaalilla valittavan pormestarin mallia on kannatettu siitä syystä, että sen on uskottu vahvistavan ja piristävän kuntademokratiaa ja kuntalaisten osallistumista (Sancino ja Castellani 2016; Wollmann 2004; 2014).

\section{Johtamisen selkeys}

Johtamismallin muutosta perustellaan myös johtamisen selkeydellä. Pormestarin on uskottu tuovan tunnistettavan johtohahmon, ja pormestarimallilla onkin tavoiteltu johtamisen, päätöksenteon ja tilivelvollisuuden selkeytymistä ja parempaa vastuusuhteiden läpinäkyvyyttä. (DCLG 2011; Fenwick ja Elcock 2014; Hambleton ja Sweeting 2004; Sweeting ja Hambleton 2020.) Suoralla vaalilla valittavan pormestarin suosio voi kasvaa muun muassa siitä syystä, että tällaisessa mallissa kuntalaisille ja sidosryhmille on selvää, kuka kuntaa johtaa (Hambleton 2013).

Saksassa pormestarimallilla on myös tavoiteltu selkeyttä. Pormestarimallin on lisäksi uskottu parantavan johdettavuutta, hallittavuutta ja sujuvuutta, ja sen avulla on pyritty välttämään kaksoisjohtajuuteen liittyviä riskejä esimerkiksi poliittisen ja ammatillisen johdon konflikteista. (Wollmann 2004.)

James Svaran ja Douglas Watsonin (2010) mukaan pormestarimallia on kannatettu Yhdysvalloissa silloin, kun politiikalle on haluttu saada kasvot ja muutoinkin lisätä läpinäkyvyyttä ja vastuullisuutta. Myös Tampereen pormestarimallin siirtymisen taustalla oli ajatus, että pormestari toisi kasvot vallankäytölle ja selkeyttäisi valta- ja vastuukysymyksiä kuntalaisten suuntaan. Pormestarimalliin siirtymisellä haluttiin myös selkeyttää poliittista ohjausta. (Hakari ym. 2013.)

Aiemman tutkimuksen perusteella vaikuttaa todennäköiseltä, että kuntalaisten ja päätöksentekijöiden arvot ja uskomukset vaikuttavat voimakkaasti siihen, millaista johtamismallia he kannattavat. Eri paikoissa ja erilaisista taustoista tulevilla ihmisillä on erilainen käsitys siitä, miten hallinto ja johtaminen pitää organisoida ja miten niiden pitää toimia. Esimerkiksi Wenchi Wein ja kollegoiden tutkimuksen (2019) mukaan eri johtamismallien kannattamisella oli tilastollisesti merkitsevä yhteys kuntalaisten sosioekonomisen taustan kanssa.

Wendy Hassettin ja Douglas Watsonin (2007) mukaan pormestari- ja virkajohtamismallin paradigmat ovat samanaikaisesti läsnä kaupungeissa, mutta toisella on taipumus hallita ajattelua tiettyinä aikoina. Toimintaympäristö vaikuttaa siihen, kummalla paradigmalla on milloinkin mahdollista nousta hallitsevaan asemaan. Tiettyjen arvojen korostuminen, esimerkiksi kasvun tavoittelu, antaa tukea pormestarimallille, kun taas havaitut eettiset ongelmat kaupunginhallinnossa voivat kääntää keskustelun myötämieliseksi virkajohtajamallille. 


\section{LAADULLINEN SISÄLLÖNANALYYSI SUOMALAISESTA MEDIA-AINEISTOSTA}

Kokosimme tutkimuksen empiirisen aineiston pormestari-virkajohtajakeskustelua koskevasta suomalaisesta kirjoitetusta verkkomedia-aineistosta. Aineistona olivat Ylen ja Helsingin Sanomien julkaisemat verkkojutut, joissa käsitellään kuntien johtamismallin muutosta ja etenkin keskustelua pormestarimallista. Aineisto rajattiin Ylen ja Helsingin Sanomien tuottamaan aineistoon, sillä niissä oli tarjolla lukumääräisesti eniten aineistoa. Erityisesti Ylen tuottamassa verkkoaineistossa käsiteltiin aihetta monien eri kuntien ja alueiden näkökulmista, minkä voi olettaa rikastavan ja monipuolistavan aineistoa.

Kokosimme aineiston Ylen ja Helsingin Sanomien internetsivuilta kyseisten medioiden omien hakutoimintojen avulla. Julkaisujen aikavälin rajasimme alkamaan vuodesta 2000 ja päättymään vuoden 2020 toukokuun loppuun. Aineiston vanhimmat tekstit ovat vuodelta $2001 \mathrm{ja}$ uusimmat vuodelta 2020. Aineistoon sisältyvien 2000-luvun alun pormestarikeskustelua käsittelevien tekstien aikana pormestarimalli ei vielä ollut mahdollinen suomalaisissa kunnissa. Aineiston loppupuolen tekstit vuodelta 2020 puolestaan ovat ajalta, jolloin pormestarimalli oli jo vakiintunut vaihtoehto suomalaisessa kuntajohtamisessa. Selkeästi suurin osa aineiston teksteistä on julkaistu 2010-luvulla (75 tekstiä), 2000-luvulla julkaistuja tekstejä on aineistossa 15 kappaletta ja 2020-luvulla julkaistuja kaksi.

Aineistosta rajasimme tarkasteltavaksi sellaiset tekstit, joissa käsitellään johtamismallin vaihtamisen tai sen harkitsemisen yhteydessä esitettyjä johtamismalleihin liittyviä uskomuksia ja perusteluja. Rajauksen ulkopuolelle jätimme sellaiset tekstit, jotka käsittelivät pormestarimallia yleisemmin, mutta joissa ei tuotu esiin pormestarimalliin liittyviä perusteluja, odotuksia tai uskomuksia. Analysoitavaksi otettu aineisto koostui yhteensä 92 mediatekstistä. Yleltä on aineistossa yhteensä 45 mediatekstiä, joista kaikki ovat uutisia ja Helsingin Sanomilta 47 mediatekstiä, joista 28 on uutisia, 10 pääkirjoituksia tai kolumneja ja loput yhdeksän analyyseja tai taustoittavia tekstejä. Helsingin Sanomien jutuista 13 on julkaistu 2000-luvulla, loput 2010-luvulla. Ylen aineisto on lähes kokonaan 2010-luvulta, kaksi uutista on 2000-luvulta (v. 2009) ja kaksi uutista 2020-luvulta. Selvästi suurin osa teksteistä, yhteensä 38 kappaletta, liittyi Helsinkiin. Helsingin suurta osuutta tekstien joukossa selittänee asema pääkaupunkina sekä toisena aineistolähteenä ollut Helsingin Sanomat, jossa luonnollisestikin annetaan enemmän painoarvoa pääkaupungin asioille. Helsinkiä koskevista teksteistä 28 julkaistiin Helsingin Sanomissa. Tampereeseen liittyviä tekstejä oli yhdeksän, Vantaaseen kahdeksan ja Espooseen seitsemän. Muut aineistossa esiintyvät kunnat olivat Heinola, Hämeenlinna, Imatra, Jämsä, Lahti, Kokkola, Kotka, Kärkölä, Nokia, Oulu, Pori, Puolanka, Rovaniemi, Salo, Seinäjoki, Turku, Tuusula ja Vihti, joista jokaisesta oli kirjoitettu yhdestä neljään tekstiä. Analyysin tulokset perustuvat edellä mainittuun aineistoon kokonaisuutena. Lähdeluettelossa on mainittu ne mediatekstit, joihin tässä artikkelissa on suoraan viitattu.

Analysoimme suomalaisessa julkisessa keskustelussa esitettyjä pormestarimalliin liittyviä näkemyksiä. Kolumneissa ja analyyseissa pormestarimalliin liittyviä uskomuksia, odotuksia, tavoitteita ja perusteluja esittävät toimittajat. Uutisartikkeleissa puolestaan äänessä ovat lähinnä kuntien luottamushenkilöt ja viranhaltijat, mutta myös niissä toimittaja on valinnut, mitä juttuun päätyy.

Analysoimme media-aineistoa sisällönanalyysin keinoin muodostamamme analyysikehikon avulla tarkastellen niitä odotuksia ja uskomuksia, joita pormestarimalliin liitetään. Tähän liittyen 
peilasimme aineistoa analyysikehikon ohjaamana johtamisen ammattimaisuuteen, poliittisen johtamisen vahvistamiseen, demokratian edistämiseen sekä johtamisen selkeyteen. Analyysiprosessi eteni aineiston huolellisen lukemisen jälkeen pelkistettyjen ilmauksien muotoiluun. Pelkistämisen avulla jäsensimme johtamismalleihin kohdistuvia odotuksia ja uskomuksia. Luokittelimme pelkistetyt ilmaukset ja muodostimme näin kahdeksaan kategoriaa kuvaamaan niitä odotuksia ja uskomuksia, joita aineistossamme pormestarimalliin liitetään.

\section{PORMESTARIMALLI RISTIRIITAISTEN ODOTUSTEN KOHTEENA}

Analyysissa yhdistimme kahdeksan kategoriaa neljäksi väittämäpariksi, joissa kuvataan pormestarimalliin kohdistuvia uskomuksia ja odotuksia. Nämä analyysin tuloksena muodostamamme pormestarimallia koskevat väittämäparit ovat:

1. Demokratia vahvistuu - valta keskittyy.

2. Poliittinen johtaminen vahvistuu - johtaminen epäammattimaistuu.

3. Status quo voidaan murtaa - johtamisen aikajänne lyhenee.

4. Kunnan toiminta saa kasvot - suhde virkakoneistoon selkeytyy.

Seuraavassa kuvaamme tekemämme analyysin tulokset väittämäpari kerrallaan. Lopuksi esitämme yhteenvedon analyysista ja peilaamme sitä aiemman tutkimuksen perusteella rakentamaamme synteesiin kunnan johtamismalleihin liitettävistä piirteistä.

Kiinnostava huomio aineistosta on se, että 20 vuoden tarkastelujakson aikana pormestarimallin osalta on tapahtunut merkittäviä muutoksia suomalaisessa kuntajohtamisessa, mutta pormestarimalliin liittyvät perustelut, odotukset ja uskomukset ovat pysyneet varsin samanlaisina.

Virkajohtaja- ja pormestarimallia perustellaan osin keskenään samanlaisilla argumenteilla. Esimerkiksi tehokkuuden kasvu yhdistetiin molempiin malleihin. Lisäksi havaitsimme, että pormestarimalliin liittyy myös ristiriitaisia uskomuksia. Pormestarimallin uskotaan esimerkiksi parantavan demokratiaa, mutta myös heikentävän sitä.

\section{Demokratia vahvistuu - valta keskittyy}

Ensimmäisessä väittämäparissa tiivistyy johtamismalleista käytävässä keskustelussa usein esiin tuleva uskomus siitä, että pormestarimallin avulla voidaan parantaa kuntademokratiaa. Pormestarimalliin siirtymistä kannatetaan hyvin suurpiirteisesti määritellyn demokratian vahvistumisen vuoksi, mikä näkyy myös media-aineistossamme. Demokratian vahvistuminen nousee esille yhtenä keskeisenä argumenttina pormestarimallin puolesta. Vasta-argumenttina puolestaan esitetään, että pormestarimallin uskotaan keskittävän valtaa, mikä ei vahvista demokratiaa ja minkä vuoksi siihen ei tulisi siirtyä.

Vaikka pormestarimalliin liitetään hyvin laajasti ajatus siitä, että se vahvistaisi demokratiaa, sitä mitä demokratian vahvistumisella tarkoitetaan, ei argumenteissa määritellä kovinkaan 
täsmällisesti, jos lainkaan. Demokratian vahvistumiseen viittaavat käytännölliset argumentit voidaan jakaa neljään uskomukseen: ensinnä siihen, että pormestarimalli lisäisi kuntalaisten kiinnostusta kunnan asioihin; toiseksi siihen, että suhde kunnan ja kuntalaisten välillä voisi pormestarimallin myötä lähentyä; kolmanneksi siihen, että pormestarimalli kanavoisi virkajohtajamallia paremmin vaalituloksen kunnan johtamiseen ja neljänneksi siihen, että äänestysaktiivisuus kuntavaaleissa nousisi.

Usko pormestarimallin demokraattisuuteen on näkynyt pormestarikeskusteluissa muun muassa Kärkölässä, missä "Kärkölä-ryhmän valtuustoryhmän puheenjohtaja Tapani Suokas pitää pormestarimallia demokraattisena. - Pormestarimalli on siitä hyvä, että se tuo kansanvaltaa ja kuntalaisten ääntä paremmin kuuluviin, perustelee Suokas." (Yle/Turtola 2017). Myös Hämeenlinnaan on ehdotettu pormestarimallia, ja yhtenä argumenttina sen puolesta on käytetty demokraattisuutta: "[Hämeenlinnan] [k]okoomuksen kaupunginvaltuutettu Jenna Kankaanpää ehdottaa pormestarimallin käyttöönottoa sanomalehti Hämeen Sanomien yleisönosastokirjoituksessa 2. lokakuuta. Kankaanpää perustelee asiaa muun muassa kuntalaisdemokratian vahvistumisella." (Yle/Mustonen 2019). Kummassakaan tekstissä ei avata tarkemmin, mitä demokratian vahvistumisella tarkoitetaan.

Pormestarimallilla tavoitellaan valtuuston vallan kasvattamista. Pormestarimallin uskotaan mahdollistavan sen, että valtuuston tahto tulee paremmin esiin kunnan toiminnassa, mitä käytettiin yhtenä perusteluna pormestarimalliin siirtymiselle esimerkiksi Puolangalla, jonka kunnanhallituksen puheenjohtaja Harri Peltola totesi, että "[t]ällä ratkaisulla voitaisiin saada paremmin valtuuston ja päättäjien tahto kunnan päätöksentekoon.” (Yle/Ruokoski 2018). Salossa vihreät tekivät valtuustoaloitteen pormestarimalliin siirtymisen edellytysten selvittämisestä vuonna 2015, ja yhtenä keskeisenä perusteluna oli juuri valtuuston vallan vahvistaminen: "Valtuustoaloitteen tekijän Eeva Koskisen mielestä pormestarimalli tarjoaa mahdollisuuden valtuuston vallan vahvistamiseen" (Yle/Hjelt 2015). Teksteissä ei tarkemmin tuoda esiin, miten valtuuston valta pormestarimallin myötä vahvistuisi.

Yleisen demokratian vahvistumispuheen ja edustuksellisen demokratian vahvistumisen lisäksi pormestarimallin uskotaan lisäävän kuntalaisten kiinnostusta kunnan asioihin ja kunnallispolitiikkaan. Henkilövaalien parempi äänestysaktiivisuus on myös herättänyt uskon siihen, että pormestarimalli voisi näkyä kuntavaaleissa jopa äänestysaktiivisuuden kasvuna, kuten esimerkiksi Porissa arveltiin: "Suomessa kuntavaalien äänestysprosentti on ollut hyvin alhainen. Aina kun kyseessä on henkilövaali, mikä herättää kiinnostusta ja sitä myöden äänestysprosentti nousee, [Porin kaupunginjohtaja] Aino-Maija Luukkonen toteaa." (Yle/Tuomi ja Rantala 2013). Suomessa pormestaria ei kuitenkaan valita suoralla vaalilla, vaan pormestarin valitsee kunnanvaltuusto.

Kunnan ja kuntalaisten suhteeseen paikantuvat myös näkemykset, joissa pormestarimallin uskotaan parantavan kuntalaisten vaikutusmahdollisuuksia. Vaikka Suomessa ei olekaan käytössä suoraa vaalia pormestarin valitsemiseksi, kuntalaisten katsotaan voivan paremmin vaikuttaa pormestarin kuin kunnanjohtajan valintaan, koska pormestari valitaan kuntavaaleissa usein eniten ääniä saaneesta puolueesta. Pormestarimalli nähdäänkin kuntalaisdemokratian kannalta virkajohtajamallia parempana vaihtoehtona, kuten esimerkiksi Vantaan kaupunginhallituksen puheenjohtajana toiminut Tapani Mäkinen on todennut: "Kaupunginjohtajamalli on demokratian irvikuva. Pormestarimallissa toteutuu pitkälle viety kaupunkilaisten tahto, jos valtuuston keskuudesta valitsema on pormestarina" (Yle/Mättö 2010). 
Tämä ajatus kytkeytyy myös näkemykseen kuntavaalituloksen paremmasta kanavoitumisesta kunnan johtamiseen. Eniten ääniä saanut puolue tai muu ryhmittymä saa pormestarimallin myötä enemmän valtaa kunnan päätöksenteossa ja johtamisessa, minkä katsotaan vahvistavan demokratiaa vaalituloksen mukaisesti. Tämä näkyy esimerkiksi Tuusulan pormestarimallia koskevassa keskustelussa, jota toimittaja on kuvannut näin: "Tuusulassa pormestarimallin vahvuutena nähdään se, että poliittiset voimasuhteet näkyisivät päätöksenteossa nykyistä paremmin.” (Yle/Turtola 2016). Vaalitulos heijastuu kunnan päätöksentekoon myös pormestarin toimikauden pituuden muodossa. Perusajatuksena on, että muutokset poliittisissa voimasuhteissa näkyvät nopeammin kunnan johdossa, sillä pormestarin kausi päättyy samanaikaisesti valtuuston toimikauden kanssa. Tämä näkökulma on nostettu esiin erityisesti Helsingin johtamisjärjestelmän uudistamisen yhteydessä. "Pormestarimallissa valtuusto valitsee pormestarin ja apulaispormestarit vaalikaudeksi kerrallaan. Uudistuksen perusajatus on se, että kuntavaalien tulos näkyy aiempaa suoremmin [Helsingin] kaupungin johtamisessa." (Yle/Malminen 2016).

Kysymys demokratian vahvistumisesta pormestarimallin myötä ei kuitenkaan ole yksiselitteinen. Samaan aikaan, kun pormestarimallia perustellaan demokratian vahvistumisella, uskotaan mallin myös keskittävän valtaa. Pelkona on, että uusjaon myötä valta kasaantuu entistä vahvemmin pienelle eliitille muiden, erityisesti pienten puolueiden jäädessä ulkokehälle. Nämä pelot vallan keskittymisestä ovat nousseet esille ainakin Helsingissä "Minusta suunta on monessa mielessä väärä: tämä malli keskittää valtaa aiempaa harvempiin käsiin, [Helsingin SKP:n pääsihteeri Heikki] Ketoharju sanoo.” (Yle Uutiset 2016). Myös Porissa on herännyt samankaltaisia huolia: "Kuntapolitiikan ammattimaistuminen voi johtaa kahden kerroksen päättäjiin ja poliittisen vallan kapenemiseen, [Porin vasemmistoliiton Raisa] Ranta toteaa." (Yle/Laakso 2020).

Edellä käsitellystä käy ilmi, että demokratialla voidaan argumentoida sekä pormestarimallin puolesta, että sitä vastaan riippuen siitä, mitä demokratiaan sisällytetään, mitä sillä tarkoitetaan, ja mitä muutoksia argumentaatiossa painotetaan.

\section{Poliittinen johtaminen vahvistuu - johtaminen epäammattimaistuu}

Luottamushenkilöiden käsittelemät asiat ovat yhä monimutkaisempia ja laajempia ja edellyttävät aikaa ja mahdollisuuksia perehtyä asioihin. Samaan aikaan toimintaympäristöstä kumpuava muutospaine on kasvanut, ja muutosvauhti on nopeutunut. Pormestarimalliin siirtymisen taustalla onkin usein luottamushenkilöiden kokema tarve parantaa luottamushenkilötyön edellytyksiä esimerkiksi mahdollistamalla heille lisää aikaa luottamustehtävän hoitamiseen sekä parantamalla mahdollisuuksia kasvattaa osaamista kunnan toiminnan kannalta olennaisissa asioissa. Tarvetta johtamismallin muutokseen saattaa kiihdyttää myös luottamushenkilöiden kokemus siitä, että heidän asemansa on heikko suhteessa viranhaltijoihin.

Aineistossamme pormestarimallin uskotaankin vahvistavan poliittista johtamista. Kyse on ensinnäkin siitä, että luottamushenkilöiden työn edellytyksiä parannetaan etenkin luomalla mahdollisuuksia käyttää aikaa kunnan asioiden hoitamiseen ja kasvattaa samalla osaamista. Toiseksi kyse on siitä, että poliittiseen johtamiseen käytettäviä resursseja vahvistetaan. Kolmanneksi kyse on muutoksista vallanjaossa. Muutosten myötä poliittiset johtajat kokevat, että on tarvetta siirtää valtaa ja vastuuta viranhaltijoilta poliitikoille. 
Luottamushenkilötyön edellytysten parantamisen katsotaan olevan keskeinen edellytys poliittisen johtamisen vahvistamiselle. Pormestarimallin odotetaan vaikuttavan tähän myönteisesti kunnallispolitiikan ammattimaistumisen myötä: pormestarimallin avulla uskotaan saatavan parhaat voimat mukaan kunnan poliittiseen johtamiseen. Tästä esimerkkinä on Helsingin Sanomien toimittajan analyysissaan esittämä toteamus: "Ammattipoliitikkoihin siirtyminen toisi todennäköisesti Helsingin politiikkaan parhaat mahdolliset voimat, sillä jatkossa asioita ei tarvitsisi hoitaa vapaa-ajalla, omien töiden ohessa." (HS/Laitinen 2015b). Lisäksi pormestarimallin katsotaan mahdollistavan paremmin keskittymisen luottamushenkilötyöhön, kun siihen on käytettävissä enemmän aikaa, mikä on nostettu esiin esimerkiksi Rovaniemen perussuomalaisten aloitteessa: "Rovaniemen perussuomalaisten mukaan johtava poliitikko - - joutuu perehtymään entistä paremmin tehtäväänsä. - - hänen mahdollisuutensa toimia toimialajohtajan tai kaupunginjohtajan työparina ovat harrastepohjalta rajalliset. - - pormestari ehtisi ja kykenisi johtamaan laajaa kaupunginhallintoa sekä kaupunginhallitusta.” (Yle/Haapanen 2016).

Pelkona kuitenkin on, että johtaminen voi myös epäammattimaistua pormestarimallin myötä. Kunnanjohtajalle voidaan asettaa kelpoisuusvaatimukset, joiden avulla voidaan varmistaa valittavan johtajan kyky ja taito johtaa kuntaa. Pormestarin valinnassa tällaisia kelpoisuusvaatimuksia ei ole.

Virkajohtajan uskotaan paremmin voivan taata ammattimainen johtaminen, sillä hänen voidaan olettaa olevan kokemuksensa, koulutuksensa ja tietotaitonsa vuoksi kykenevä ja pätevä johtamistehtävään. Virkajohtajan uskotaan myös rauhoittavan päätöksentekoa ja tekevän kunnan johtamisjärjestelmästä varmemman ja vakaamman. Tämä nousi esiin esimerkiksi Turussa selvitettäessä johtamismallin uudistamista: "Kaupunginjohtajamalli toisaalta tuo pysyvyyden elementin, rauhoittaa päätöksentekoa ja korostaa virkakunnan ammattimaisuutta, arvioi [Turun kaupunginhallituksen puheenjohtaja] Lauri Kattelus." (Yle/Vähämäki 2019).

Pormestarimalliin liittyvänä riskinä nähdään johtamisen ammattimaisuuden katoaminen. Esimerkiksi Heinolan kaupunginvaltuuston puheenjohtaja Timo Ihamäen pormestarimallia koskevassa aloitteessa todetaan, että: "pormestarimallin riskit ovat myös suuret, malli saattaisi merkitä siirtymistä ammattijohtamisesta amatöörijohtamiseen" (Yle Uutiset 2009). Pormestarimalliin siirtymisen esteeksi voidaan nähdä myös se, ettei kunnassa uskota löytyvän riittävän pätevää poliitikkoa, jonka vastuulle kunnan johtohenkilön tehtävän voisi antaa. Tämä näkökanta on noussut esiin kuntapoliitikkojen pohdinnoissa esimerkiksi Lahdessa: "Rehellisesti. Kuka meistä valtuutetuista korvaisi kaupunginjohtajan? Puoluepoliittinen osaaminen ei pätevöitä kaupungin johtamiseen, sanoi kokoomuksen Sari Niinistö." (Yle/Enlund ja Ahjopalo 2018) ja Jämsässä: "Äkkiseltään tuntuu, että meillä ei kovin montaa vaihtoehtoa ole, jotka sen pestin pystyvät hoitamaan - kuntavaaleihinkin on välillä vaikeaa löytää ehdokkaita. - - sanoo Jämsän kaupunginhallituksen puheenjohtaja Piritta Rantanen (sd.)” (Yle/Seppälä 2016).

Virkajohtajamallissa ongelmana nähdään, että virkajohtajat käyttävät poliittista päätösvaltaa, joka kuuluisi luottamushenkilöille. Pormestarimallin uskotaan korjaavan tämän ongelman. Luottamushenkilötyön edellytysten vahvistamisen uskotaan tasapainottavan vallan jakautumista, kun pormestarin ajatellaan pystyvän muodostamaan vastavoiman viranhaltijoiden vallankäytölle. Tämä on näkynyt esimerkiksi Helsingin pormestarimalliin liittyvässä keskustelussa: "Nyt valtaa on valunut virkamiehille ja paikkoihin, joissa ei toimita vaaleista saadulla mandaatilla”, sanoo vihreiden ryhmänjohtaja Emma Kari (vihr)." (HS/Laitinen 2015c). 


\section{Status quo voidaan murtaa - johtamisen aikajänne lyhenee}

Kolmannessa väittämäparissa kyse on johtamisen tavoista, kuntien uudistamisen kulttuurista sekä kuntien imagosta. Pormestarimalliin siirtyminen nähdään tilaisuutena murtaa status quo eli niin sanottu asioiden vallitseva tila ja tuoda uusia ajatuksia ja tapoja kunnan johtamiseen. Pormestarimalliin liitetään aineistossamme muun muassa sellaisia ominaisuuksia kuin dynaamisuus, nopeus ja eurooppalaisuus. Virkajohtajamallia puolestaan pidetään kankeana, hitaana ja byrokraattisena, mutta myös vakaana ja varmana. Samalla kun pormestarimallia perustellaan dynaamisuudella ja nopeudella, pelätään, että johtamisen aikajänne lyhenee ja kunnan johtamisesta tulee entistä tempoilevampaa.

Pormestarimallilla tavoitellaan paitsi uutta johtamismallia, myös uudenlaista kulttuuria ja imagoa kunnalle. Sen avulla uskotaan voitavan nostaa kunnan profiilia ja uudistaa vanhoja toimintamalleja laajemminkin. Kunnan painoarvon ja profiilin nostaminen on tuotu esiin esimerkiksi Helsingin Sanomien pääkirjoituksessa: "Parhaimmillaan suosittu pormestari voisi nostaa Helsingin profiilia ja painoarvoa valtakunnanpolitiikassa" (HS/Mikkonen 2016). Jämsässä pormestarimallista valtuustoaloitteen tehnyt "[Uusi Jämsä -ryhmän valtuutettu Seija] El Sayed sanoo, että Jämsässä tarvitaan vanhojen toimintamallien uudistamista. - Pormestarimalli toisi avoimempaa, läpinäkyvämpää toimintakulttuuria ja ehkä nopeampaa reagointia ja toimintavalmiutta, El Sayed pohtii." (Yle/Rantanen 2016).

Pormestarimallia pidetään uudenlaisena, ajassa kiinni olevana johtamistapana, jonka uskotaan nopeuttavan kunnan päätöksentekoa. Pormestarimallin uskotaan tuovan kunnan toimintaan vauhtia ja kehitystä sekä aiemmasta poikkeavaa päätöksenteko- ja johtamiskulttuuria. Tämä perustelu nousi esille esimerkiksi Turun johtamismallipohdinnoissa, joiden yhteydessä kaupunginhallituksen puheenjohtaja Lauri Kattelus totesi pormestarimallin olevan "ehkä modernimpi, dynaamisempi ja asioita eteenpäin vievä malli.” (Yle/Vähämäki 2019). Pormestarimallilla tavoitellaan siis laajempaa, kunnan toimintaa ravisuttavaa kulttuurista muutosta, mikä näkyy myös Helsingin johtamisjärjestelmän muutosta koskeneessa keskustelussa. Esimerkiksi Helsingin Sanomien pääkirjoituksessa pormestarimalli nähtiin mahdollisuutena jättää hyvästit pölyttyneelle virastokulttuurille: "Tässä on mahdollisuus: nyt on hetki, jolloin tsaarinaikuiselle ja patriarkaaliselle jäykälle virkakoneistolle voidaan sanoa 'hei hei'. Päätöksentekohuoneita voidaan tuulettaa ikkunoiden lisäksi myös ovien kautta." (HS Pääkirjoitus 2016).

Pormestarimalliin liitettävän dynaamisuuden kääntöpuolena ovat uskomukset siitä, että johtamisen aikajänne lyhenee ja päätöksenteon pitkäjänteisyys kärsii. ”Toisaalta pormestarimallia on arvosteltu siitä, että kaupungin johto vaihtuisi liian tiuhaan eikä pitkäjänteisiä muutoksia saataisi tehtyä neljässä vuodessa”, toteaa Ylen toimittaja Katri Kirsi Helsingin johtamisjärjestelmän uudistamista taustoittavassa uutisessaan (Yle/Kirsi 2016).

Suomalaisen kuntajohtamisjärjestelmän yhtenä peruskivenä on pidetty kuntajohtamisen vakautta. Luottamushenkilöt vaihtuvat, mutta virkajohtaja pysyy. Tämän on ajateltu tuovan myös pitkäjänteisyyttä, luotettavuutta ja vakautta, joiden uskotaan toteutuvan pormestarimallia paremmin virkajohtajamallissa. Tähän viittasi myös Helsingin kaupunginjohtaja Jussi Pajunen Helsingin johtamisjärjestelmää koskevassa esityksessään: "Suuren ja monialaisen kaupunkiorganisaation johtaminen edellyttää ammattimaista ja pitkäjänteistä johtamista, jonka kaupunginjohtajamalli mahdollistaa" (HS/Laitinen 2015a). 


\section{Kunnan toiminta saa kasvot - suhde virkakoneistoon selkeytyy}

Neljäs väittämäpari kuvaa uskomuksia pormestarimallin vaikutuksesta kunnan hallintasuhteisiin. Pormestarimallin uskotaan parantavan kunnan ja kuntajohdon suhdetta kuntalaisiin ja lisäävän kuntapäätöksenteon avoimuutta sekä lähentävän kuntalaisia ja päätöksentekijöitä.

Pormestarin katsotaan tuovan kasvot kunnalle, sen hallinnolle, päätöksenteolle ja poliittiselle vallankäytölle. Kuntajohtamisen kasvottuminen on noussut esille pormestarimallikeskusteluissa ainakin Helsingissä, Lahdessa, Turussa, Vantaalla, Vihdissä ja Porissa. Porin kaupunginjohtaja Aino-Maija Luukkonen totesi, että pormestarimallin myötä "[p]olitiikalla olisi selkeät kasvot ja henkilö, jonka puoleen kuntalaiset voisivat kääntyä.” (Yle/Tuomi ja Rantala 2013). Vallan ja päätöksenteon kasvottumisen puolestaan uskotaan lähentävän kuntalaisia ja päätöksentekijöitä ja pormestarin uskotaan olevan helpommin lähestyttävissä kuin kunnanjohtajan. "Ainakin Tampereen ja Pirkkalan kokemusten perusteella se on tuonut avoimuutta lisää ja suoraa vaikutusmahdollisuutta kuntalaisille. Pormestari on helpommin lähestyttävä kuin kaupunginjohtaja, [Nokian kaupunginvaltuuston puheenjohtaja Jari] Haapaniemi tiivisti seminaarissa kerrottua." (Yle/Matson-Mäkelä 2013).

Kunta-kuntalaissuhteen parantumisen lisäksi pormestarimallilla uskotaan olevan myönteisiä vaikutuksia myös kuntaorganisaation sisäisiin hallintasuhteisiin. Niiden uskotaan selkeytyvän pormestarimallin myötä, mitä on pidetty pormestarimallin suurena etuna verrattuna virkajohtajamalliin. ”Tässä nyt valitussa mallissa piirtyy selkeä raja poliittisen päätöksenteon ja poliittisen johtamisen sekä toisaalta virkamiesjohtamisen ja virkamiesvallankäytön välille, valaisee [Helsingin] johtamisen jaoston puheenjohtaja Lasse Männistö (kok)." (Yle/Konttinen 2015).

Poliittisen ja viranhaltijajohdon suhteen selkeytyminen liittyy myös monissa kunnissa esiintyvään tapaan, jossa ylimmän virkajohdon valinnoissa valittavan henkilön puoluetaustalle annetaan suuri painoarvo, vaikka kyseessä on objektiivisessa virkaroolissa toimiva henkilö. Kyse on siis poliittisin perustein tehdyistä virkanimityksistä, mikä on nähty yhtenä pontimena johtamismallin muutokselle pormestarimallia harkinneissa kunnissa, esimerkiksi Salossa, Tampereella, ja Helsingissä: "Uudistusta on vauhdittanut apulaiskaupunginjohtajien valinnoista kummunnut kritiikki. Veronika Honkasalo (vas.) luonnehti viimeaikaisia valintoja 'hämäräksi systeemiksi'. -Se on syönyt poliittista luottamusta meiltä kaikilta. Kaupunkilaisten silmissä olemme kaikki olleet osa tätä mätää tuolileikkiä, Honkasalo epäili.” (HS/Salomaa 2016.)

\section{JOHTOPÄÄTÖKSET}

Tässä artikkelissa olemme tarkastelleet pormestarimalliin liitettyjä tavoitteita, siihen kohdistuvia odotuksia ja uskomuksia aiemman tutkimuksen sekä pormestarimallia koskevan media-aineiston analyysin avulla. Tutkimustamme ohjaavana kysymyksenä oli, mitä pormestarimallilla tavoitellaan, mitä siltä odotetaan ja miten pormestarimallin valintaa perustellaan?

Pyrkimyksenämme on ollut tuottaa uutta ymmärrystä pormestarimalliin liitettävistä merkityksistä. Ymmärrystä olemme tavoitelleet aiemman tutkimuksen sekä media-aineiston analyysin 
avulla. Analyysin tuloksena olemme tunnistaneet edellisessä luvussa kuvatut neljä väittämäparia, jotka tiivistävät pormestarimalliin liittyviä uskomuksia, odotuksia ja tavoitteita.

Demokratian vahvistuminen on keskeinen argumentti, johon pormestarimallia koskevissa käsityksissä nojataan, mikä näkyy myös aiemmassa kansainvälisessä tutkimuksessa (esim. Fenwick ja Elcock 2014; 2016; Sancino ja Castellani 2016; Wollmann 2004; 2014). Tämä on ymmärrettävää, sillä demokratian vahvistuminen on tavoite, josta kaikkien toimijoiden on helppo olla yhtä mieltä, tai ainakin kenenkään on vaikea vastustaa sitä. Kuntajohtamiskontekstissa demokratian vahvistuminen edustaa universaalia arvoa, joka on validi kaikelle yleisölle niin kauan kuin sitä ei määritellä tarkasti (ks. Perelman 1982, 26-27). Demokratian käsitettä käytetäänkin pormestarikeskustelussa hyvin epämääräisesti, eikä sen sisältöä juurikaan avata. Demokratian vahvistuminen voi pitää sisällään esimerkiksi valtuuston vallan vahvistumisen, vaalit voittaneen puolueen vallan vahvistumiseen, luottamushenkilöiden vallan vahvistumisen suhteessa viranhaltijoihin ja kuntalaisten vallan vahvistumisen. Kun keskustelun taso jää melko abstraktiksi, voidaan demokratiaa käyttää käsitteenä, joka yhdistetään johonkin yleiseen hyvään.

Samalla demokratian vahvistuminen voi kuitenkin tarkoittaa myös vallan keskittymistä, jossa demokraattisesti vaaleilla valittujen päätöksentekijöiden valta kyllä voi kasvaa, mutta tämä koskee käytännössä vain pientä osaa valtuutetuista (ks. myös Svara ja Watson 2010). Pormestarimallin myötä syntyy uudenlaisia valtapositioita ja vallankeskittymiä, joissa valtaa on paljon. Näin ollen demokratian vahvistuminen voikin olla pienen poliittisen eliitin vahvistumista, elitististä demokratiaa, mikä voi olla hyvin kaukana niistä tulkinnoista ja tavoitteista, joihin pormestarimalliin siirtymistä koskevassa keskustelussa on viitattu. Onko poliittisen eliitin vahvistumisessa kyse silloinkin vielä demokratian vahvistumisesta vai jopa päinvastoin, kollektiivisen demokraattisen päätöksenteon heikkenemisestä? (Ks. myös Jäntti ym. 2021.)

Pormestarimalliin siirtymistä perustellaan myös poliittisen johtamisen vahvistumisella, mikä on noussut esiin myös aiemmassa tutkimuksessa (ks. esim. Hambleton ja Sweeting 2004). Tämäkin on tavoite, johon luottamushenkilöiden on helppo yhtyä, ja jossa on helppo saavuttaa puoluerajat ylittävä konsensus. Poliittisen johtamisen vahvistuminen esitetään pormestarikeskustelussa luottamushenkilöiden vallan vahvistamisena suhteessa viranhaltijoihin. Kuitenkin kyse on tästäkin näkökulmasta vallan keskittymisestä. Tavoite poliittisen johtamisen vahvistumisesta ymmärretään helposti koko luottamushenkilöorganisaatiota koskevana näkymänä, mutta pormestarimalli itsessään ei välttämättä vahvista kuin pormestarin ja mahdollisten apulaispormestarien valtaa. Välillisesti pormestariston on mahdollista omalla toiminnallaan vaikuttaa siihen, että poliittinen johtaminen vahvistuisi laajemminkin. Tällaista mekanismia ei kuitenkaan ole sisäänrakennettu pormestarimalliin, vaan poliittisen johtamisen laajempi vahvistuminen riippuu pormestariston toiminnasta sekä suhteista muihin ryhmiin sekä viranhaltijaorganisaatioon.

Vasta-argumenttina poliittisen johtamisen vahvistumiselle on suomalaisessa pormestarikeskustelussa käytetty sitä, että johtaminen epäammattimaistuu pormestarimallin myötä. Aiemmassa tutkimuksessa esiin on noussut se, että virkajohtajamallia perustellaan sen ammattimaisuudella (Choi ym. 2013). Pelkona pormestarimalliin liittyen on, että poliittisen johdon kyvyt, taidot ja pätevyys eivät riitä kunnan johtamiseen, kun heidän positionsa vahvistuu esimerkiksi syvällistä asiantuntemusta vaativien sektoreiden johtamisen osana. Laajemmin tulkittuna politiikan ammattimaistuminen ja hallinnon altistuminen poliittiselle vaikuttamiselle näyttäytyy 
vastatrendinä uuden julkisjohtamisen (New Public Management, NPM) ajatuksille (Halligan 2020). Luottamushenkilötyön ammattimaistumisen ja poliittisen avustajiston myötä hallinto ja johtaminen altistuvat aiempaa enemmän ja aiempaa varhaisemmassa vaiheessa poliittiselle vaikuttamiselle, mikä näkyy erityisesti suuremmissa kaupungeissa, mutta on Markku Temmeksen (2014) havaintojen mukaan jo aiemmin muuttanut valtion keskushallinnon toimintaa. Tämä kehityssuunta haastaa valmisteluvallan ja päätösvallan selkeän erottamisen toisistaan ja liudentaa näiden positioiden tarkkarajaisuutta.

Suomalainen keskustelu pormestarimallista kiinnittyy vahvasti ajatukseen uudenlaisesta, dynaamisesta, staattisen nykytilan murtavasta, muutosta luovasta johtamistavasta. Tällainen ajattelu näyttää korostuvan juuri suomalaisessa keskustelussa, sillä aiemmassa tutkimuksessa nämä argumentit eivät nouse esiin. Tutkimuksemme siis täydentää aiempaa tutkimusta tuoden esille myös muutoksen tavoittelun näkökulman. Vallitsevan tilan muuttamiseen uskotaan päästävän pormestarimallin avulla, vahvistamalla poliittista johtajuutta. Muutoksen ei nähdä mahdollistuvan staattisena pidetyn, byrokraattisen virkajohtajamallin ja kollektiivisen päätöksenteon kautta, vaan monitasoisen poliittisen järjestelmän kautta. Pormestarimallilla haetaan dynaamisuutta, vanhan ravistelua ja uutta otetta johtamiseen, mutta samalla pelätään isoja muutoksia ja lyhytjänteisyyttä, jonka uskotaan liittyvän dynaamisempaan johtamisotteeseen. Vaikka pormestarimallissa valtaa keskitetään, ja sen nähdään mahdollistavan muutoksen, pelätään samalla, että tätä keskitettyä valtaa käytetään. Pormestarimallilla tavoitellaan kuntajohtamisen rytminmuutosta vastaiskuna tasaiseen virkamiesharmauteen ja kollektiivisten kompromissien hieromisen hitauteen. Pormestarimallissa tämä tapahtuu pienelle poliittiselle eliitille keskittyvän vallan kautta. Tämä on merkittävä muutos, kun siirrytään suomalaiselle kuntapolitiikalle tyypillisestä, kollektiiviseen vallankäyttöön ja johtamiseen perustuvasta päätöksenteosta politiikan superpositioihin ja vahvaan yksilöjohtamiseen.

Pormestarimallin uskotaan parantavan kuntaorganisaation suhdetta kuntalaisiin, mikä nousee esiin myös aiemmassa tutkimuksessa (DCLG 2011; Lodge 2012). Pormestarin vahva valtapositio ja näkyvyys helpottavat vallan kasvottumista. Kunta-kuntalaissuhteen paranemiseen liittyy myös uskomus siitä, että pormestarimalli lähentää päätöksentekijöitä ja kuntalaisia. Hallintasuhteiden uskotaan selkeytyvän pormestarimallin myötä myös kuntaorganisaation sisällä, poliittisen ja viranhaltijajohdon välillä, kun viranhaltijat eivät enää käytä poliittista valtaa, vaan toimivat poliittisesti valittujen pormestareiden tukena. Kunnan- ja kaupunginjohtajien tehtävä nähdään sellaisena, että siinä joudutaan välttämättä toimimaan ja ottamaan kantaa tavalla, joka sopii paremmin poliittisten johtajien rooliin.

Analyysimme vahvistaa ja täydentää kansainvälisen kuntajohtamismalleihin liittyvän tutkimuksen havaintoja pormestarimalliin liitettävistä uskomuksista ja odotuksista. Pelot johtamisen epäammattimaistumisesta ja vallan keskittymisestä (Svara ja Watson 2010) sekä tavoitteet poliittisen johtamisen (esim. Hambleton ja Sweeting 2004; Jäntti ym. 2021) ja demokratian vahvistumisesta (Fenwick ja Elcock 2014; 2016; Sancino ja Castellani 2016; Wollmann 2004; 2014) sekä johtamisen selkeytymisestä (DCLG 2011; Fenwick ja Elcock 2014; Sweeting ja Hambleton 2020; Hambleton ja Sweeting 2004) ovat näkyvissä niin Suomessa kuin aiemmassa kansainvälisessä tutkimuksessa.

Analyysimme nostaa esiin myös sellaisia huomioita, joita aiemmassa aihepiirin tutkimuksessa ei ole tullut esiin. Suomalaisessa pormestarikeskustelussa korostuvat voimakas tarve 
muutokseen ja odotukset pormestarimallista vallitsevan tilan murtajana. Pormestarista haetaan siis päätöksenteon ja kunnan uudistumisen vauhdittajaa.

Kaikkiin analyysin tuloksena muodostamiimme väittämiin liittyy kysymys siitä, miten tavoitteisiin, odotuksiin ja uskomuksiin liittyviä käsitteitä tulkitaan. Retorisesti näihin tavoitteisiin liittyy sellaisten universaalisti arvokkaiden käsitteiden käyttö, joiden avulla voidaan luoda näkymä yleisestä hyvästä. Itse prosessia voidaan tarkastella hallinnonuudistamisessa tyypillisen hämärän horisontin idean avulla. Hämärä horisontti tarkoittaa sitä, että kun tavoitteet ovat riittävän epämääräisiä tai yleisiä, jotta niihin on helppo yhtyä, on niiden kannattaminen mahdollista erilaisista positioista ja intresseistä lähtien. (Airaksinen ym. 2012, 52.) Yksityiskohtaisempi tarkastelu ja tarkempi määrittely kuitenkin tuovat näkyväksi käsitteisiin liittyvän tulkintojen avaruuden ja ne monet näkökulmat, joita käsitteiden takana oleviin tavoitteisiin ja uskomuksiin liittyy. Uudistuksesta päätettäessä hämärä horisontti aiheuttaa optisen harhan, jossa uudistuksen tuottama tulevaisuus näyttää hyvältä. Se siis auttaa viemään uudistuksen läpi, mutta samalla uudistukseen liittyvien konfliktien esiin tuleminen ja ratkaiseminen viivästyvät. Mitä epämääräisemmin, hämärän horisontin turvin, uudistuksessa edetään, sitä myöhemmässä vaiheessa konfliktit tulevat näkyviksi (emt. 104).

Kokonaisuutena tarkastellen aiemman kansainvälisen tutkimuksen ja suomalaisen mediaaineiston analyysin perusteella näyttää siltä, että pormestarimalliin liitettävät uskomukset, odotukset ja tavoitteet ovat varsin abstrakteja. Tavoitteiden yleismaailmallisuuden ja yleiseen hyvään verhoutumisen lisäksi yhteistä näyttää olevan se, että pormestarimallilla uskotaan päästävän perustavanlaatuiseen ja kokonaisvaltaiseen kuntajohtamisen muutokseen, jossa muutoksen kohteena ei ole pelkästään kunnan johtohahmo, vaan laajemmin kuntajohtamisen rytmi, suunta ja perusta. Keinona näihin tavoitteisiin pääsemiseksi pormestarimallissa on poliittisen johtamisen kasvottaminen ja vahvistaminen. Tämä tapahtuu siirtämällä valtaa pois viranhaltijoilta poliitikoille sekä keskittämällä valtaa ja luomalla politiikan superpositioita.

\section{LÄHTEET}

\section{Viitattu media-aineisto}

Yle/Enlund, Tapio ja Ahjopalo, Janne. 2018. Lahti päätti siirtyä pormestarimalliin - tutkija huolissaan demokratiavajeesta ja hyvä veli -verkostoista. Yle Uutiset, Pormestarit 12.3.2018. https://yle.fi/uutiset/3-10112791

Yle/Haapanen, Liisa. 2016. Rovaniemen perussuomalaiset: Kaupunki tarvitsee pormestarin. Yle Uutiset, Pormestarit 11.4.2016. https://yle.fi/uutiset/3-8802682

Yle/Hjelt, Yrjö. 2015. Vihreät haluaa Saloon pormestarin. Yle Uutiset, Kotimaa 2.2.2015. https://yle.fi/ uutiset/3-7774870

Yle/Kirsi, Katri. 2016. Pormestarin johtama Helsinki, mitä ihmettä se käytännössä tarkoittaa? Yle Uutiset, Kotimaa 22.2.2016. https://yle.fi/uutiset/3-8683843

Yle/Konttinen, Matti. 2015. Helsinki saanee sittenkin pormestarin - Pajusen esitys vahvasta kaupunginjohtajasta jyrättiin. Yle Uutiset, Kotimaa 23.11.2015. https://yle.fi/uutiset/3-8475812 
Yle/Laakso, Antti. 2020. Pormestarimalli saa Porissa tukea SDP:ltä ja vihreiltä - kokoomuksesta ei täyttä tyrmäystä. Yle Uutiset, Pormestarit 11.3.2020. https://yle.fi/uutiset/3-11249786

HS/Laitinen, Joonas. 2015a. Helsingin Jussi Pajunen kaipaa vahvaa johtajaa ja superpoliitikkoja. Helsingin Sanomat, Kaupunki/HS-Analyysi 29.10.2015. https://www.hs.fi/kaupunki/art-2000002862953. html

HS/Laitinen, Joonas. 2015b. Pormestarin valinta vaikuttaa varmalta - mitä se tarkoittaa helsinkiläisten kannalta? Helsingin Sanomat, Kaupunki/HS-Analyysi 24.11.2015. https://www.hs.fi/kaupunki/art2000002868312.html

HS/Laitinen, Joonas. 2015c. Valtaistuinpeli alkaa Helsingissä - puolueet hyväksymässä pormestarimallin. Helsingin Sanomat, Kaupunki/HS-analyysi 4.6.2015. https://www.hs.fi/kaupunki/art2000002829270.html

Yle/Malminen, Ulla. 2016. Helsingin pormestarimalli sai vihreää valoa kaupunginhallitukselta. Yle Uutiset, Kotimaa 29.2.2016. https://yle.fi/uutiset/3-8708823

Yle/Matson-Mäkelä, Kirsi. 2013. Pormestari myös Nokialle? Yle Uutiset, Politiikka 22.3.2013. https://yle. fi/uutiset/3-6549511

HS/Mikkonen, Minttu. 2016. Helsinki tarvitsee pormestariksi koko kansan suosikin - kuka se voisi olla? Helsingin Sanomat, pääkirjoitus 1.3.2016. https://www.hs.fi/paakirjoitukset/art-2000002888800.html

Yle/Mustonen, Kari. 2019. Pormestari vetämään Hämeenlinnaa 2020-luvulle? Yle Uutiset, Pormestarit 2.10.2019. https://yle.fi/uutiset/3-11001573

Yle/Mättö, Ville. 2010. Pormestaristako hohtoa ja brändäystä Vantaalle? Yle Uutiset, Pormestarit 18.8.2010. https://yle.fi/uutiset/3-6164158

HS Pääkirjoitus 2016. Helsingin johtoa odottaa iso muutos. Helsingin Sanomat, Pääkirjoitus 30.7.2016. https://www.hs.fi/paakirjoitukset/art-2000002913360.html

Yle/Rantanen, Annika. 2016. Valtuustoaloite: Jämsän selvitettävä siirtymistä pormestarimalliin. Yle Uutiset, Jämsä 3.6.2016. https://yle.fi/uutiset/3-8928418

Yle/Ruokoski, Vilma. 2018. Puolangasta saattaa tulla Suomen pienin pormestarin johtama kunta. Yle Uutiset, Kunnat 8.5.2018. https://yle.fi/uutiset/3-10195666

HS/Salomaa, Marja. 2016. Helsingistä tulee Suomen kolmas pormestarin johtama kaupunki. Helsingin Sanomat, Kaupunki 22.6.2016. https://www.hs.fi/kaupunki/art-2000002907645.html

Yle/Seppälä, Antti. 2016. Jämsän luottamusmiesjohto ei innostu pormestarista. Yle Uutiset, Jämsä 6.6.2016. https://yle.fi/uutiset/3-8930073

Yle/Tuomi, Sinikka ja Rantala, Kati. 2013. Porin kaupunginjohtaja: Uuden suurkunnan johtoon pormestari. Yle Uutiset, Kotimaa 9.12.2013. https://yle.fi/uutiset/3-6970983

Yle/Turtola, Ilona. 2016. Pormestari kunnan johtopaikalla on vielä harvinaisuus - nyt sellaista miettii Tuusula. Yle Uutiset, Kotimaa 9.5.2016. https://yle.fi/uutiset/3-8863942

Yle/Turtola, Kati. 2017. Pikkukunta havittelee pormestaria. Yle Uutiset, Kärkölä 5.12.2017. https://yle.fi/ uutiset/3-9963162

Yle Uutiset 2009. Heinolaan pormestari? Yle Uutiset, Pormestarit 23.2.2009. https://yle.fi/uutiset/3-5726138

Yle Uutiset 2016. Pormestarimalli tulossa - miten käy Helsingin pitkäjänteisen kehittämisen? Yle Uutiset, Kotimaa 16.3.2016. https://yle.fi/uutiset/3-8744717

Yle/Vähämäki, Hannu. 2019. Turun uuden johtamisjärjestelmän vaihtoehdot viimeistelyä vaille valmiit. Yle Uutiset, Turku 24.9.2019. https://yle.fi/uutiset/3-10985290 


\section{Tutkimuskirjallisuus}

Airaksinen, Jenni, Laine, Toni, Kyösti, Anni, Markkola, Antti, Härkönen, Helena, Afflekt, Antti, Lehtola, Jenni ja Paananen, Henna. 2012. Kuntauudistus prosessina. Valtiovarainministeriön julkaisuja 23/2012. Helsinki: Edita.

Carr, Jered. 2015. What Have We Learned about the performance of Council-Manager Government? A Review and Synthesis of the Research. Public Administration Review 75:5, 673-689. https://doi.org/10.1111/puar.12415

Choi, Cheon Geun, Feiock, Richard ja Bae, Jungah. 2013. The Adoption and Abandonment of CouncilManager Government. Public Administration Review 73:5, 727-736. https://doi.org/10.1111/puar.12097

DCLG, Department of Communities and Local Government. 2011. Localism Bill: creating executive mayors in the 12 largest English cities Impact assessment. http://www.parliament.uk/documents/ impact-assessments/IA11-010AL.pdf. Viitattu 1.2.2021.

Feiock, Richard, Jeong, Moon-Gi ja Kim, Jaehoon. 2003. Credible Commitment and Council-Manager Government: Implications for Policy Instrument Choices. Public Administration Review 63:5, 616-625. https://doi.org/10.1111/1540-6210.00324

Fenwick, John ja Elcock, Howard. 2014. Elected Mayors: Leading Locally? Local Government Studies 40:4, 581-599. https://doi.org/10.1080/03003930.2013.836492

Fenwick, John ja Elcock, Howard. 2016. Elected mayors in England: leaders or managers? International Journal of Public Leadership 12:4, 289-300. https://doi.org/10.1108/IJPL-04-2016-0018

Goldsmith, Mike ja Larsen, Helge. 2004. Local Political Leadership: Nordic Style. International Journal of Urban and Regional Research 28:1, 121-133. https://doi.org/10.1111/j.0309-1317.2004.00506.x

Guérin, Élodie ja Kerrouche, Éric. 2008. From Amateurs to Professionals: The Changing Face of Local Elected Representatives in Europe. Local Government Studies 34:2, 179-201. https://doi.org/10.1080/03003930701852260

Hakari, Kari. 2009. Tampereen toimintamallin uudistus. Vastaus tulevaisuuden haasteisiin. Teoksessa Arto Haveri, Kaija Majoinen ja Anni Jäntti (toim.) Haastava kuntajohtaminen. Helsinki: Suomen Kuntaliitto, 84-92.

Hakari, Kari, Stenvall, Jari ja Rannisto, Pasi-Heikki. 2013. Pormestarimalli ja kaupungin johtamisen muutos. Uuden julkisen hallinnan näkökulma. Hallinnon tutkimus 32:2, 129-145.

Halligan, John. 2020. Reforming Public Management and Governance: Impact and Lessons from Anglophone Countries. Cheltenham, UK: Edward Elgar.

Hambleton, Robin. 2013. Elected mayors: an international rising tide? Policy \& Politics 41:1, 125-128. https://doi.org/10.1332/030557313X663279

Hambleton, Robin ja Sweeting, David. 2004. U.S. Style Leadership for English Local Government? Public Administration Review 64:4, 474-488. https://doi.org/10.1111/j.1540-6210.2004.00393.x

Hassett, Wendy ja Watson, Douglas. 2007. Civic battles: When cities change their form of government. Boca Raton: Pr Academics Press.

Haveri, Arto. 2020. Tulevaisuuden kuntajohtaminen. Kunnallisalan kehittämissäätiön julkaisuja. https:// kaks.fi/wp-content/uploads/2020/06/tulevaisuuden-kuntajohtaminen_web.pdf. Viitattu 1.2.2021.

Haveri, Arto, Airaksinen, Jenni ja Paananen, Henna. 2015. Uuden sukupolven kuntajohtajat. Acta 261. Kuntaliitto. Helsinki: Kuntaliitto. 
Haveri, Arto, Jäntti, Anni, Johanson, Jan-Erik, Parkkinen, Jonne ja Paananen, Henna. 2021. Pormestarimallin vaikutus poliittiseen johtamiseen sekä poliittisen ja virkajohdon yhteistyöhön. Teoksessa Anni Jäntti, Arto Haveri ja Pasi-Heikki Rannisto (toim.), Tehokasta ja demokraattista kaupunkihallintaa? Helsingin johtamisjärjestelmän uudistuksen akateeminen kokonaisarviointitutkimus. Helsinki: Helsingin kaupunki, 24-47.

HE 192/1994 vp. Hallituksen esitys Eduskunnalle kuntalaiksi. Annettu Helsingissä 30.9.1994. Saatavilla sähköisesti osoitteesta: https://finlex.fi/fi/esitykset/he/1994/19940192. Viitattu 1.2.2021.

ICMA. 2011. International City/County Management Association: Municipal Form of Government survey 2011. https://icma.org/documents/icma-survey-research-2011-municipal-form-government-survey-summary. Viitattu 1.2.2021.

Jäntti, Anni, Haveri, Arto ja Airaksinen, Jenni. 2021 (tulossa). Pormestari vai virkajohtaja - miksi kunnan johtamismallin muuttamista harkitaan? Hallinnon tutkimus 40(2).

Jäntti, Anni, Haveri, Arto ja Rannisto, Pasi-Heikki. (toim.) 2021. Tehokasta ja demokraattista kaupunkihallintaa? Helsingin johtamisjärjestelmän uudistuksen akateeminen kokonaisarviointitutkimus. Helsinki: Helsingin kaupunki.

Katainen, Mervi. 2005. Suomalainen pormestari - poliitikko vai virkamies? Kuntapormestarimallien vertailu strukturaalis-funktionalistisesta ja eurooppalaisesta näkökulmasta. Pro gradu -tutkielma. Helsinki: Helsingin yliopisto.

Korkeila, Laura. 2017. Pormestarimalli ja tilivelvollisuus. Pro gradu -tutkielma. Vaasa: Vaasan yliopisto. Kuntalaki 410/2015. Annettu Helsingissä 10.4.2015. Saatavilla sähköisesti osoitteesta: https://www.finlex. fi/fi/laki/ajantasa/2015/20150410?search\%5Btype\%5D=pika\&search\%5Bpika\%5D. Viitattu 1.2.2021.

Larsen, Helge. 2002. Directly Elected Mayors - Democratic Renewal or Constitutional Confusion? Teoksessa Janice Caulfield ja Helge Larsen (toim.), Local Government at the Millenium. Wiesbaden: Urban Research International, VS Verlag für Sozialwissenschaften, 111-133. https://doi.org/10.1007/978-3-663-10679-1_6

Leinonen, Jaana. 2012. Monelta suunnalta on suitsia suussa, mutta niiden kanssa on elettävä. Johtamisen liikkumavara kunnanjohtajan silmin. Akateeminen väitöskirja. Acta nro 232. Lapin yliopisto. Helsinki: Suomen Kuntaliitto.

Liljeroos, Riikka. 2018. Pormestari hallinnon ja politiikan rajapinnassa. Pormestarimallin vaikutukset viranhaltijaorganisaation ja luottamushenkilöorganisaation väliseen valtasuhteeseen. Pro gradu -tutkielma. Tampere: Tampereen yliopisto.

Lodge, Guy. 2012. Mayors and democratic renewal in England. Teoksessa Tom Gash ja Sam Sims (toim.), What Can Elected Mayors Do for Our Cities? Lontoo: Institute for Government, 29-33.

Magnier, Annick. 2006. Strong Mayors? On Direct Election and Political Entrepreneurship. Teoksessa Henry Bäck, Hubert Heinelt ja Annick Magnier (toim.), The European Mayor. Wiesbaden: VS Verlag für Sozialwissenschaften, 353-376. https://doi.org/10.1007/978-3-531-90005-6_16

Marin, Sanna. 2017. Pormestarien Suomi: tarkastelussa poliittisen johtamisen ammattimaistuminen viidessä Suomen kaupungissa. Pro gradu -tutkielma. Tampere: Tampereen yliopisto.

Marsh, Alex. 2012. Is it time to put the dream of elected mayors to bed? Policy and Politics 40:4, 607-611. https://doi.org/10.1332/030557312X657808

Marttinen, Matias. 2019. Kenelle kunnanjohtaja ja pormestari ovat tilivelvollisia toimistaan? Tutkimus Tampereen ja Tuusulan pormestarimalleista tilivelvollisuuden muutosten näkökulmasta. Pro gradu -tutkielma. Turku: Turun yliopisto. 
Moilanen, Riikka. 2020. Pormestarille tietä antakaa: pormestarimallin toteutuminen politiikan ja hallinnon välisessä suhteessa. Pro gradu -tutkielma. Rovaniemi: Lapin yliopisto.

Perelman, Chaim. 1982. The Realm of Rhetoric. Notre Dame: University of Notre Dame.

Røiseland, Asbjørn ja Vabo, Signy Irene. (toim.) 2020. Folkevalgt og politisk leder. Cappelen Damm Akademisk. https://doi.org/10.23865/noasp.80.ch1

Sancino, Alessandro ja Castellani, Lorenzo. 2016. New development: Directly elected mayors in Italy -creating a strong leader doesn't always mean creating strong leadership. Public Money \& Management 36:2, 153-156. https://doi.org/10.1080/09540962.2016.1118945

Sandberg, Siv. 2016. Kunnallisten luottamushenkilöiden ajankäyttö vuosina 1995-2015. ARTTU2-tutkimusohjelman julkaisusarja nro 5/2016. Helsinki: Suomen Kuntaliitto.

Stenvall, Jari ja Airaksinen, Jenni. 2009. Manse mallillaan. Tampereen mallin arviointi ja palveluinnovaatiot. Acta 211. Helsinki: Suomen Kuntaliitto.

Svara, James. 2003. Effective Mayoral Leadership in Council-Manager Cities: Reassessing the Facilitative Model. National Civic Review 92:2, 157-172. https://doi.org/10.1002/ncr.14

Svara, James ja Watson, Douglas. (toim.) 2010. More than mayor or manager: Campaigns to change form of government in America's large cities. Washington, DC: Georgetown University Press.

Sweeting, David. 2003. How strong is the Mayor of London? Policy \& Politics 31:4, 465-478. https://doi.org/10.1332/030557303322439353

Sweeting, David ja Hambleton, Robin. 2020. The dynamics of depoliticisation in urban governance: Introducing a directly elected mayor. Urban Studies 57:5, 1068-1086. https://doi.org/10.1177/0042098019827506

Temmes, Markku. 2014. Politiikan politisoituminen. Virkamiestyön kriisi. Hallinnon tutkimus 33:1, $54-62$.

Uutissuomalainen 2020. USU-gallup: Vain joka kuudes haluaa kotikuntaansa pormestarin seuraavaksi johtajaksi - eniten kannatusta on Helsingin ja Uudenmaan alueella 11.11.2020. https://www.uutissuomalainen.fi/uutissuomalainen/3157595

Wei, Wenchi, Butler, John ja Jennings Jr, Edward. 2019. The Determinants of Municipal Structures on a Political-Administrative Dimension. American Review of Public Administration 49(2), 189-202. https://doi.org/10.1177/0275074018814876

Wollmann, Hellmut. 2004. Urban leadership in German local politics: the rise, role and performance of the directly elected (chief executive) mayor. International Journal of Urban and Regional Research 28:1, 150-164. https://doi.org/10.1111/j.0309-1317.2004.00508.x

Wollmann, Hellmut. 2014. The directly-elected mayor in the German Länder - introduction, implementation and impact. Public Money \& Management 34:5, 331-337.

https://doi.org/10.1080/09540962.2014.945798 


\section{KIRJOITTAJATIEDOT}

\section{ANNI JÄNTTI}

HTT, tutkijatohtori

Sosiaalipolitiikka

Yhteiskuntatieteiden tiedekunta

Tampereen yliopisto

anni.jantti@tuni.fi

\section{ARTO HAVERI}

HTT, professori

Kunta- ja aluejohtaminen

Johtamisen ja talouden tiedekunta

Tampereen yliopisto

arto.haveri@tuni.fi

JENNI AIRAKSINEN

HTT, yliopistonlehtori

Kunta- ja aluejohtaminen

Johtamisen ja talouden tiedekunta

Tampereen yliopisto

jenni.airaksinen@tuni.fi 